\title{
THE DISPUTES BETWEEN TJIPTO MANGOENKOESOEMO AND SOETATMO SOERIOKOESOEMO: SATRIA VS. PANDITA
}

\author{
Takashi Shiraishi
}

In 1918 major debates took place between Tjipto Mangoenkoesoemo, a leading proponent of Indies nationalism, and Soetatmo Soeriokoesoemo, a leader of the Committee for Javanese Nationalism (Comite voor het Javaansche Nationalisme), first over the question of Indies versus Javanese nationalism, and then over the problem of Javanese cultural development. The language of the debates was Dutch, not Javanese or Malay (Indonesian), and 1918, when they occurred, was the year the Volksraad (People's Council) was founded. It was apparently with the Council's opening in mind that Tjipto and Soetatmo engaged in these debates and the audience to which both of them were appealing was the group in the Budi Utomo which was most enthusiastic about the opening of the Volksraad. ${ }^{1}$ In an atmosphere where this event was viewed as marking the dawn of a new epoch, a question keenly felt among followers of Budi Utomo was the political and cultural relevance of Javanese tradition to "progress." Tjipto and Soetatmo addressed this question in their disputes and vied for ideological hegemony among those Dutcheducated lower-priyayi who made up the group in Budi Utomo that supported the Volksraad. The first debate was in fact published in March 1918, just after Tjipto's nomination as a member of the Volksraad and two months before its formal opening. The second debate took place at the Congress for Javanese Cultural Development, which was held in Solo in July 1918, in conjunction with the annual meetings of the Budi Utomo, PHGB (Perserikatan Guru Hindia Belanda), and Oud'OSVIA'-nen-bond, and just after the end of the Volksraad's first session. The theme of the Congress, Javanese cultural development, was reminiscent of Governor-General van Limburg Stirum's opening speech to the Volksraad, where he remarked: "it [the Volksraad] will be able to attain perfection as the organ to express the will of the population of the whole Netherlands Indies only after civilization has come to maturity in all parts of the archipelago." ${ }^{3}$

1. For the Budi Utomo's attitude to the opening of the Volksraad, see Akira Nagazumi, The Dawn of Indonesian Nationalism: The Early Years of the Budi Utomo, 1908-1918 (Tokyo: Institute of Developing Economies, 1972), pp. 118-30, 140-50.

2. "Nota over het congres voor javaansche cultuurontwikkeling van B. J. O. Schrieke, 27 Juli 1918," Verbaal [Vb] 14-1-19-50 [hereafter abbreviated as "Nota van Schrieke"], in the Archives of the ex-Colonial Ministry, Ministry of Internal Affairs (Ministerie van Binnenlandse Zaken), The Hague, also included in R. C. Kwantes, ed., De Ontwikkeling van de Nationalistische Beweging in NederlandschIndië, le Stuk, 1917-Medio 1923 (Groningen: Willink, 1975). The PGHB was established by the Budi Utomo and was under its guidance. Nagazumi, Dawn of Nationalism, p. 118.

3. Simon Lambertus van der Wal, ed., De Volksraad en de Staatkundige Ontwikkeling van Nederlands-Indië: een Bronnenpublicatie, eerste Stuk, 1891-1926 (Groningen: Wolters, 1965), p. 599. 
In retrospect, however, the scope of the debates went far beyond the opening of the Volksraad, because in them Tjipto and Soetatmo explicitly addressed the question of the place of the pergerakan (movement) in Java's history and culture and what its future course should be now that it was again increasing in importance. The dominant theme of the pergerakan was changing from kemajuan (progress) to democracy and sama rata sama rasa (equality and solidarity). The ideological influence of the socialist Indische Sociaal Democratische Vereeniging (ISDV) was already apparent, and even Tjokroaminoto, president of the Centraal Sarekat Islam (CSI), was talking about some capitalism as "sinful." 4 The Semarang Sarekat Islam (SI) under Semaoen's leadership was emerging as the center of the socialist wing of the CSI. In Yogyakarta, the Personeel Fabrieks Bond (PFB) headed by Soerjopranoto was in the making. Also gaining influence was the Djawa Dipa movement, which proposed democratization of the Javanese language by abolition of kromo as a remnant of "feudal" Javanese culture. ${ }^{5}$

Sama rata sama rasa was first coined in 1918 by Mas Marco Kartodikromo, an editor of the Semarang SI's organ Sinar Hindia, who composed the pantun "Sama Rasa dan Sama Rata" while in jail. ${ }^{6}$ Sama rata sama rasa immediately gained wide currency in the pergerakan, with Kiyai Haji Sirad of Banyumas in 1918 already depicting the golden age that would be realized with the coming of the Ratu Adil as sama rata sama rasa. ${ }^{7}$ In the same year, Haji Fachroeddin, a leader of Muham-

4. Although the Sarekat Islam's second national congress in 1917 explicitly condemned "sinful capitalism," Tjokroaminoto attempted to mollify those SI members who were merchants by identifying "sinful capitalism" with "foreign capitalism," thus implying that Indonesian capitalism was acceptable. See George McT. Kahin, Nationalism and Revolution in Indonesia (Ithaca: Cornell University Press, 1952), pp. $72-73$.

5. Djawa Dipa was established in Surabaya in March 1917 by Tjokrosoedarmo, then a commissioner of the CSI, and its aim was to abolish kromo Javanese and to make ngoko, which they called basa hasli, the standard Javanese. The word "dipa" came from aji dipa, the magic weapon Wibisana used in the wayang story of the Ramayana cycle. Oetoesan Hindia, the CSI organ under Tjokroaminoto's editorship, claimed that the Djawa Dipa would enlighten the old-fashioned (kaum kolot) just as Wibisana restored light to the minds of the troop of apes led by Kiskenda. For the Djawa Dipa movement, see "De Djowodipo-Beweging," De Indische Gids [hereafter $I G], 41$ (1919), pp. 220-23, and P. J. Zürcher, Jr., "Djawa Dipa," $/ G, 42$ (1920), pp. 691-95.

6. Mas Marco Kartodikromo, "Sama Rasa dan Sama Rata," Sair Rempah-rempah, 1 (Semarang: Sinar Djawa, 1918). Marco's career as a radical nationalist started when he joined the Solo SI as a commissioner and as an editor of Sarotomo, some time in late 1912 or early 1913. From early 1917 to late 1919 , he was a commissioner of the Semarang SI and an editor of Sinar Hindia. At the 1919 CSI congress, he was appointed a commissioner of CSI, but apparently he did not have any organizational base, as can be seen from the fact that he was in charge of journalism, and not of a region, like Haji Fachroeddin, a Muhammadiyah leader, who was in charge of the Yogyakarta region. In 1920, Mas Marco moved to Yogyakarta, and he sided with the Soerjopranoto-Haji Agus Salim-Haji Fachroeddin faction on the question of party discipline. In 1922, however, he once again returned to the PKI and, after Haji Misbach was banished to Manokwari, he became the chairman of the Solo Sarekat Rakyat in 1924. In 1927 he was arrested and banished to Boven Digul, where he died in 1932 .

7. For Kiyai Haji Sirad's Ratu Adil movement, see Mailrapport [hereafter Mr.] $135 \mathrm{x} / 20,182 \mathrm{x} / 20,441 \mathrm{x} / 20$. 
madiyah and a commissioner of the CSI who sided with the Yogyakarta-based Soerjopranoto-Haji Agus Salim faction of the party, also composed a pantun entitled "Sama rata sama rasa." 8

But most of the pergerakan's leaders, especially those from the SI, did not reflect on the movement's significance or try to place it in the context of the Javanese cultural tradition. For them, its meaning was too apparent. In the mainstream of the pergerakan, the SI was the very embodiment of the spirit of the time. Besides, its leaders were internationalist in their outlook and they saw no point in defining the place of the pergerakan in Javanese history and culture. Both Tjipto and Soetatmo were also deeply involved in the pergerakan, but, since Tjipto was a leader of Insulinde and Soetatmo a leader of Budi Utomo, they stood somewhat on its periphery. They were thus in a position to address those members of the Budi Utomo who were deeply concerned with their Javanese heritage in the age of pergerakan. In this article, I want to discuss this question and show how Tjipto and Soetatmo reached diametrically opposing views of the pergerakan.

\section{Javanese or Indies Nationalism}

Tjipto Mangoenkoesoemo, ${ }^{9}$ born in 1886 in Ambarawa and a graduate of STOVIA, was one of the first leaders of the pergerakan. He was active in the early days of the Budi Utomo and then joined Douwes Dekker in establishing the short-lived but overtly nationalist Indische Partij in 1912. In 1913, he was exiled to Holland together with Soewardi Surjaningrat and Douwes Dekker because of anti-Dutch propaganda activities in the Comite Bumiputera. Allowed to return to Java in 1914 because of illness, he joined Insulinde, the successor of the Indische Partij. He served as a member of the Hoofdbestuur of Insulinde for some time and also carried out propaganda activities for the party, especially on the north coast of Java. ${ }^{10}$ But he was under close police surveillance and his activities were always subject to police harassment. Therefore, although he was respected as a man who had once sacrificed himself for the people and although his writings were probably widely read, he had hardly any organizational basis in the pergerakan. He was a lone satria, fiercely criticizing Dutch colonial domination and the feudal priyayi order, advocating the nationalism of all the Indies and the improvement of the lot of ordinary people who had no title, rank, or wealth (the kromo), and remaining courageous and true to his cause. For all these reasons Governor-General van Limburg Stirum appointed him a member of the Volksraad when it was established.

Soetatmo Soeriokoesoemo, born in 1888, came from the Paku Alam House in Yogyakarta and was a proponent of Javanese nationalism. In 1914, he established the Committee for Javanese Nationalism and published its monthly journal Wederopbouw [Reconstruction]. On the editorial committee of the magazine were Soetatmo, Abdul Rachman, and Satiman Wirjosandjojo. Later, Noto Soeroto and Soerjopoetro joined them as foreign correspondents, and, when Satiman moved to Jambi, his younger brother Soekiman Wirjosandjojo replaced him. All the leading members of the Committee for Javanese Nationalism belonged to the younger generation of Budi Utomo, and their patrons included Prince Mangku Negara and Radjiman Wediodipoero. The

8. Islam Bergerak, June 20, 1918.

9. For Tjipto's career as a nationalist, see M. Balfas, Dr. Tjipto Mangoenkoesoemo: Demokrat Sedjati (Jakarta/Amsterdam: Djambatan, 1952), and Savitri Prastiti Scherer, "Harmony and Dissonance: Early Nationalist Thought in Java" (M.A. thesis, Cornell University, 1975), pp. 102-81.

10. See Mr. $1621 / 16,1622 / 16,1856 / 16$. 
publication of the magazine Wederopbouw was possible only with the financial assistance of Prince Mangku Negara, who himself contributed articles under the name of Daha. ${ }^{11}$ Not very much is known about Soetatmo's career in the pergerakan. He joined the Indische Partij when it was founded in 1912 and was also a member of the Comite Bumiputera in 1913. ${ }^{12}$ Some time later he became a member of the Hoofdbestuur of Budi Utomo and held this position until his death in 1924 . He was also a leading member of the Adhi Darma association of the Paku Alam House, which was established by Soerjopranoto and from which the PFB was born in 1918. In 1921, he was elected to represent the Budi Utomo in the Volksraad, and the following year joined Soewardi Soerjaningrat in founding Taman Siswa, serving as its first president with Soewardi as the secretary.

The first debate between Tjipto and Soetatmo on Indies versus Javanese nationalism was published in 1918 as a booklet titled Javaansch of Indisch Nationalisme. This appeared as a special issue of Wederopbouw, and it has been widely discussed in studies of the early nationalist movement, so it will be considered only very briefly here. ${ }^{13}$

In this debate, Soetatmo advocated Javanese nationalism, arguing that the nation could and should be built on the basis of common culture and language. Javanese nationalism had its basis in the common culture, language, and history of the Javanese, whereas the cultural bases of Indies nationalism were nonexistent or, at best, a product of Dutch colonial rule. Javanese nationalism was the means of selfexpression for the Javanese, while the Indies nationalism of the Indische Partij or the Islamism of the SI were no more than a reaction to Dutch colonial domination of the Indies. Therefore, he argued, only Javanese nationalism had the sound cultural basis on which the Javanese could establish their future political community.

In reaction to this argument of Soetatmo, Tjipto defended Indies nationalism. In his opinion, what was totally lacking in Soetatmo's view was world historical development. He argued that Europe was clearly more advanced than Asia, and therefore the Javanese could learn from European historical experience the direction in which the national formation in the Indies would go. The Indies were indeed composed of diverse ethnic groups with each ethnic group having a different culture and language, but Java had lost its sovereignty and was only a part of the Dutch-dominated Indies. The fatherland of the Javanese was no longer Java but the Indies, and the task of the national leaders was to work for Indies nationalism.

Tjipto's idea of a nation of "Indiers" was a community of politically independent individuals or demokrat sedjati, while the Javanese nation, as viewed by Soetatmo, was based on the cultural identity of the Javanese. But this does not necessarily mean that Tjipto was a simple-minded modernist, totally denying the relevance of

11. "Nota van Schrieke." Soekiman Wirjosandjojo was then a student at the STOVIA and was later to establish the Partai Islam Indonesia.

12. For Comite Bumiputera and its activities, see Kenji Tsuchiya, "Genjumin Iinkai wo meguru Shomondai: Shihai to Teiko no Yoshiki ni kanrenshite [Soewardi Soerjaningrat and his 'Als ik een Nederlander was']," Tonan Aiia Kenkyu, 15, 2 (1977), pp. 131-52.

13. R.M.S. Soeriokoesoemo, A. Muhlenfeld, Tjipto Mangoenkoesoemo, and J. B. Wens, "Javaansch of Indisch Nationalisme?" (Semarang, 1918). See, also, Kenji Tsuchiya's extremely provocative argument in his "Jawa Chishikijin no Seio-ninshiki wo meguru Shomondai, 1913-1922 [Javanese Intellectuals' Conception of the West: A Case Study of Soewardi Soerjaningrat and His Colleagues from 1913 to 1922], "Tonan Ajia Kenkyu, 15, 4 (1978), pp. 530-51. 
Javanese culture to Indies nationalism. And, as we will see, Soetatmo's argument was based on his conviction that the enormous resilience of Javanese culture enabled it to transcend modernity. But we will also see that Tjipto's idea was based in a more subtle way on his own understanding of Javanese culture and history. To appreciate this point, we need to consider their second debate, which concerned the direction and strategy of Javanese cultural development.

\section{The Congress for Javanese Cultural Development}

The Congress for Javanese Cultural Development was held in Solo from July 5 to $7,1918 .^{14}$ The initiative for the Congress came from the leaders of the Committee for Javanese Nationalism and their patrons. The topics to be discussed at the Congress strongly reflected the intellectual and political interests of these Javanese nationalists. The questions put forward at the Congress were thus: in which direction should the development of the Javanese proceed, how could the Javanese reconstruct (wederopbouwen) their great civilization of the past, and which roles should be assigned to Western civilization and Javanese culture in the task of reconstruction. The discussion at the Congress centered on the meaning and future development of Javanese culture and the strategy for realizing them. 15

Since the initiative for the Congress came from the leaders of the younger generation of Budi Utomo and from Europeans and Indo-Europeans such as van Hinloopen Labberton and Muhlenfeld, and since Javanese nationalists were heavily represented, no leader of stature in the national pergerakan except Tjipto participated in its sessions. Tjokrosoedarmo, a commissioner of the CSI, strongly criticized the anti-Islamic tone of the Congress. ${ }^{16}$ Tirtodanoedjo from Djawa Dipa, in

14. The formal steering committee of the Congress for Javanese Cultural Development was composed of: Honorary Chairman Prince Mangku Negara, Chairman R. Sastrowidjono, Secretary S. Koperberg, Commissioners P. A. Hadiwidjojo, R. M. A. Woerjaningrat, Wediodipoero (Dr. Radjiman). The idea of holding a congress of this sort came from two sources. Several months before the opening of the Volksraad, D. van Hinloopen Labberton, a well-known theosophist, entertained the idea of holding a congress for Javanese language, and the preparatory committee he convened in Batavia was composed of Dr. Hoesein Djajadiningrat, Dr. F. D. K. Bosch, and Dr. B. Schrieke as members, and by Dr. Hazeu, the Advisor for Native Affairs, as an honorary member. They had in mind Prince Mangku Negara as the chairman of the projected congress. In the meantime, a similar plan was also under way among members of the Budi Utomo in Solo, and the Dutch group in $\mathrm{Ba}$ tavia decided to let them take the initiative in organizing the congress. Although Koperberg, a member of the ISDP, was appointed secretary of the steering committee, due to his close relationship with Prince Mangku Negara and others, it seems certain that the leadership of the congress was in the hands of the "Wederopbouw group." See "Nota van Schrieke." Also see Congres voor Javaansche CultuurOntwikkeling: Programma en Tekstboekje (Semarang: Misset, 1918). On the relative sizes of the Budi Utomo's branches in Yogyakarta and Solo and the relationship between them in 1918, see Nagazumi, Dawn of Nationalism, pp. 132-33.

15. "Nota van Schrieke." Also see Congres: Programma en Tekstboekje.

16. "Nota van Schrieke." In the first part of 1918 , the CSI was especially sensitive to anti-Islamism, because of the fury generated among pious Muslims by the Djawi Hiswara affair. On January 11, 1918, Diawi Hiswara, a newspaper in Solo whose chief-editor was Martodharsono, a former protege of Haji Samanhudi and a guru kebathinan, carried an article by Djojodiroro, in which Mohammad was depicted as a gin-drinker and an opium-smoker. The article was seen as an attack 
reaction to the antidemocratic stance of the Committee for Javanese Nationalism, argued that the present task of the pergerakan was not the reconstruction of Javanese culture but its democratization, especially the democratization of the Javanese language. He announced the convening of the Djawa Dipa Congress in conjunction with the coming Third National Congress of the CSI, which was scheduled to be held in Surabaya in September and October of 1918. The ISDV also criticized the aristocratic character of the Congress. In its journal, Suara Rakjat, Darsono argued that examples of old Javanese civilization such as Borobudur had been created by the despotic rule of the raja. ${ }^{17}$ All these criticisms against Javanese nationalism were to the point. But by boycotting the Congress, the leaders of the CSI, Djawa Dipa, and the ISDV chose not to confront the Javanese nationalists directly and by so doing they missed the opportunity of presenting their own view of Javanese cultural development.

Nine people presented papers at the Congress, five Javanese and four Dutch, but three of the speakers' papers were either mediocre in quality or not directly relevant to the questions raised. Four of the remaining six papers took the standpoint of Javanese nationalism, those of Soetatmo and Satiman from the Committee for Javanese Nationalism, Radjiman Wediodipoero, and an Indo-European "Javanese nationalist," A. Muhlenfeld. The other two papers, of Tjipto and J. E. Stokvis, were very critical of Javanese nationalism from the respective standpoints of Indies nationalism and ethical enlightenment.

In the paper Soetatmo presented at the Congress, ${ }^{18}$ he argued that the future development of Javanese culture was predestined by its inherent nature, and that the task to be undertaken was to let its essence unfold through opvoeding (upbringing). What he meant by the essence of Javanese culture was beauty (schoonheid) and by opvoeding, he meant moral upbringing. In his view, the moral domain of human beings was part of the higher order controlled by the divine; and the task of moral upbringing should be assumed by the pandita (sage) who transcended all the differences between parties, religions, and particular interests. According to Soetatmo, a pandita was a person who lived a life of asceticism and meditation in the mountains, completely cut off from, and outside, social life, so that he learned to control himself completely and was knowledgeable of the law of the higher order to which every human nature is subject. Two generations earlier, once boys had reached a certain age their fathers would send them to stay with a pandita for their moral upbringing. Living with the pandita was in and of itself of greater and higher value for the children than daily moral lessons given by the school teacher, for the invisible moral power of the pandita, radiating from his great character, gave the children their moral upbringing. The end product of this was the perfection of self for the disciple and his descendants. The training provided

on Islam, and, in reaction, the Comite Tentera Kanjeng Nabi Mohammad with headquarters in Surabaya was formed to defend Islam. In February and March, mass rallies were held all over Java to protest the article. In Solo, the subcommittee of TKNM was formed on February 22, 1918, in which Haji Misbach, president of Sidik Amanat Tableq Fatonah, and Haji M. Hisamzaijni, an advisor to the CSI, played leading roles. In reaction to the campaign of the TKNM, the Committee for Javanese Nationalism distributed a pamphlet cautioning against the religious fanaticism of the TKNM, thus inviting the anger of both the TKNM and CSI. "Algemeene beschouwingen over de Inlandsche pers in 1918," Mr. 264x/18.

17. "Nota van Schrieke."

18. "Prae-advies van R. M. Soetatmo Soeriokoesoemo," Congres: Programma en

Tekstboekje, pt. 2 . 
by Western education could not possibly produce such perfection, because it was essentially an intellectual, and not a moral, upbringing. But, to Soetatmo's regret, the pandita had been lost in the past, and now only the wayang remained as a reservoir of Javanese wisdom and as a means for the moral education of Javanese youth. Yet only by following the path of moral upbringing could Javanese culture develop. Such was the main thrust of Soetatmo's argument.

Tjipto's paper was partly devoted to criticizing Soetatmo's arguments and partly to elucidating his own view of Javanese cultural development. ${ }^{19}$ In responding to Soetatmo, Tjipto saw the remnants of the Javanese cultural tradition as what he called Hinduism, that is, the coexistence of the people and the gods, the caste system, and the wayang. In his opinion, there was indeed poetry in traditional Hinduism, but it had now become an obstacle to Javanese progress. A very good example was the caste system, based on Hindu tradition, which was retained in the principle of hereditary succession of the bupati. This had now become a pillar of Dutch colonial rule and was suffocating whatever creativity the Javanese had. Times had changed and the Javanese had changed with them. Therefore, Tjipto saw improvement of the people's welfare as their most important task and argued that, for that task, the Javanese should learn Western science and technology. In his view, Soetatmo's idea of opvoeding was a simple illusion. Soetatmo had argued that the pandita could control himself completely, but Tjipto claimed that, even if Javanese culture placed a higher value upon the moral than the material and did not allow the material to dominate at the expense of the inner and moral life, it still could not suppress egoism. On the contrary, one lesson of Javanese history was that in the past men had devoted themselves to the practice of asceticism and meditation and had trained themselves to curb their diverse passions, only in order to secure the future of their descendants, usually with the very concrete aim of gaining the blessing of the gods so that one of their descendants could some day ascend to the throne of Java. Tjipto therefore argued that what the Javanese needed now was not Soetatmo's opvoeding, but something that would contribute to the improvement of the people's welfare. For this, Javanese culture and language was, in his view, totally useless.

In which direction, then, should Javanese culture develop? He argued that it would acquire a totally new character as the Javanese reincarnated themselves as "Indiers" and that, in that process of transformation, Javanese culture, especially the elements which had now become obstacles to the people's progress, would die out, because it was traditional Javanese Hinduism, especially its institutional expression in the caste system, that suffocated the creativity and initiative of the people and brought about their moral death. The people's liberation from moral death could only be realized, in his view, with the destruction of Javanese culture and the reincarnation of the Javanese into "Indiers."

Such were the arguments of Soetatmo and Tjipto at the Congress. It will now be clear that their disputes over the future direction and strategy of Javanese cultural development both centered on the concept of opvoeding. This is important, because the Dutch "Ethical" idea was also based on a concept of opvoeding. In this context the controversy between Soetatmo and Tjipto can be seen as based on their differing views of how to achieve a nationalist definition of the concept of opvoeding. Dutch Ethical arguments justified colonial domination in the Indies by the idea of tutelage and association, which actually meant the Dutch bore the burden of introducing the light of modernity into the darkness of traditional and backward Java. The political autonomy of the Indies, in whatever form, might be seen

19. Tjipto Mangoenkoesoemo, "Iets over Javaansche Cultuurontwikkeling: Praeadvies uitgebracht voor het Congres $5 / 6$ Juli 1918," ibid., pt. 3. 
as the goal, but, as the opening speech of the Governor-General showed, it was the ultimate goal, to be achieved only after the task of civilizing Java had been completed. In Dutch Ethical thinking, the concept of opvoeding meant intellectual upbringing or education as the means of enlightenment. ${ }^{20}$ In the light of the importance of opvoeding in Ethical thinking, Soetatmo's paper, which was an attempt to reformulate and redefine the concept within a Javanese cultural context, was extremely provocative. He, in effect, was denying that the Western concept of intellectual upbringing had any relevance to the Javanese situation, replacing it by the Javanese concept of moral upbringing, which was none other than the perfection of a man's moral character through the unfolding of the essence of Javanese culture. It was the negation of Dutch Ethical thought. Redefining the concept of opvoeding thus, Soetatmo turned it into the principle of Javanese nationalism.

In contrast, Tjipto's argument did not seem to differ much from Ethical thought. It is, therefore, quite understandable that Schrieke, who submitted a very detailed official report on the Congress to the Governor-General, should find Tjipto's argument very reasonable, and lament that his paper was not more fully discussed at the Congress. On the other hand, Schrieke referred to Soetatmo as "this slightly conceited half-baked youngster." ${ }^{21}$ But Schrieke naturally was an Ethicus, and if we accept his assessment of the Congress uncritically, we will miss Tjipto's implicit point, and the real problem at issue between him and Soetatmo. The Congress was held in the late 1910s, and by that time the superiority of Western science and technology and the legitimacy of progress were already undisputed. ${ }^{22}$ Although Soetatmo argued for moral upbringing, he did not mean to denigrate Western science and technology. His argument was that the Javanese could go beyond modernity by following the path of moral upbringing--thus they could fasten modernity to Javanese cultural tradition. The problem at issue between Soetatmo and Tjipto, although never explicitly discussed in their papers, was not whether modernity was desirable or whether intellectual or moral upbringing should come first, but how tradition should be conceptualized and how the age and the world of pergerakan should be understood. Soetatmo and Tjipto were not philosophers, sitting back and reflecting on the abstract question of modernity and tradition, but were leaders committed to the pergerakan, and to defining their place, as Javanese intellectuals, within it.

\section{"Reconstruction"}

Why did Soetatmo see the pandita as crucial in the moral upbringing of the Javanese and what did he mean by the essence of beauty (schoonheid) which moral upbringing should permit to unfold? How were "opvoeding" and "beauty" related to his concepts of "the age of pergerakan" and his own place in it?

One of the most important features of a Javanese nationalist interpretation of Javanese history was the view that the era of the Kingdom of Majapahit was its golden age. In this view, Java reached the peak of its glory in the era of Hindu-Javanese

20. See the very interesting paper Stokvis presented at the Congress: "Praeadvies van Stokvis," ibid., pt. 2. For a good discussion of Ethical thought, see Kenji Tsuchiya, "Genjumin Iinkai wo meguru Shomondai," especially pp. 143-45.

21. "Nota van Schrieke." Schrieke contemptuously remarked in this report that the combination of half-baked Western development and the Oriental world-view would not and could not produce the synthesis of the East and West.

22. See "Prae-advies van Satiman Wirjosandjojo," Congres: Programma en Tekstboekie, pt. 3 . 
Majapahit and, after its collapse in the fifteenth century under the onslaught of the petty Islamic states on the north coast, Java had experienced a history of continual decay, cultural confusion, internal disorder, and finally colonization. The traditional Javanese way of interpreting history saw it not as a unilinear process from the immemorial past to the indefinite future but as a successive alternation of the golden age (jaman mas) and the time of madness (jaman edan). Javanese nationalists, then, saw the era of Majapahit as the pure and ideal type of the golden age, in which they could search for the essence of Javanese culture whereby they could reconstruct Java's second golden age. ${ }^{23}$

To put it another way, they saw the time in which they lived as the time of madness. This interpretation was, naturally, not new. Two generations before them Ranggawarsita had also seen his time as the time of darkness. ${ }^{24}$ Although Soetatmo and Ranggawarsita saw their lifetimes as the time of madness, however, the mood of the time had already changed. Soetatmo depicted the age of pergerakan in which he lived in his booklet Sabdo-Panditto-Ratoe (published in 1920) in the following words:

In the meantime, the Indies are experiencing chaos, a hell; men cannot distinguish friends from enemies. The Government plays double roles, now of the friend, then as the enemy, now progressive, then reactionary. Men fight against friends and go along with enemies, while they are definitely confident that they are fighting enemies. Nobody knows the right end and the struggle breaks out everywhere: nobility against nonnobility, kromo against ngoko, capital against (wage) labor, ruler against ruled, government against the people; the society is upside down and is totally out of joint. Such is the present picture of the Indies. ${ }^{25}$

In Soetatmo's view, the current state system and the response of the pergerakan to it were both wrong. He compared the capitalist state to a family in which "the father is henpecked and the mother, only indulging in prinking herself up, neglects her duties to the children." But "if the mother persistently neglects her duties, collision is unavoidable. And when it--this collision--comes, the children will triumph. The roles will be turned upside down and the father and mother will

23. See "Prae-advies van A. Muhlenfeld" and "Prae-advies van Wediodipoero (Dr. Radjiman)," ibid., pt. 2. For the concepts of jaman mas and jaman edan, see Benedict R. $\mathrm{O}^{\prime} \mathrm{G}$. Anderson, "The Idea of Power in Javanese Culture," in Culture and Politics in Indonesia, ed. Claire Holt et al. (Ithaca, N.Y.: Cornell University Press, 1972), pp. 1-69, and also "A Time of Darkness and a Time of Light: Transposition in Early Indonesian Nationalist Thought," in Perceptions of the Past in Southeast Asia, ed. A. Reid and David Marr (Singapore: Heinemann, 1980), pp. 219-48. Islamic intellectuals of reformist tendency naturally saw Javanese history in a different way. Shortly after the Congress for Javanese Cultural Development, Islam Bergerak (published in Solo under the editorship of Haji Misbach and Haji Fachroeddin) carried Habromarkoto's article which argued that Java's decay was brought about not because the Javanese converted from Hinduism to Islam, but because the Javanese had not followed fully enough the path shown by the Prophet Mohammad, who was as a fighter (prajurit) never afraid to die. Islam Bergerak, August 1, 1918.

24. See R. Ng. Ranggawarsita, Kitab Kalatida (Kediri: Tan Khoen Swie, 1927). See also Anderson, "Time of Darkness."

25. Soetatmo Soriokoesoemo, Sabdo-Panditto-Ratoe: Het Recht is van den Wijze (Weltevreden: Indonesische Drukkerij, 1920), p. 5. 
have to obey. And we will here see the picture of the Democratic state." ${ }^{26}$ Soetatmo saw the tide toward a democratic state as inevitable, and, to his regret, in the age of pergerakan the people were indeed accepting with enthusiasm the social democratic principle of same rata sama rasa as the only sound basis of democracy. ${ }^{27}$ Even Tjipto, "the man of Insulinde, who always preaches with lofty courage the rights of the little man . . now openly professes democracy and wants to place the people on the throne." ${ }^{28}$ But people's government (volksregeering), that is, democracy on the basis of sama rata sama rasa, was, in Soetatmo's view, an illusion. For "if men had equal rights, they would have no duties to fulfill, each individual would rely on himself, on his own rights and no society is possible. The child would be left to his own lot, because he insists that men respect his rights. There would be no unity, but only differences, no order but chaos." 29 Thus Soetatmo viewed with a deep sense of crisis the rise of the pergerakan guided by the principle of democracy and sama rata sama rasa.

But, in contrast with Ranggawarsita, who could see no way out of this madness, Soetatmo and other members of the Committee for Javanese Nationalism were confident that they had already discovered the way out. As an Indo-"Javanese nationalist," Muhlenfeld pointed out in his paper presented at the Congress that the cultural renaissance of nineteenth-century Surakarta had been the isolated attempts of people such as Susuhunan Paku Buwono IV and V, Mangku Negara IV, and the Jasadipura family, including Ranggawarsita. But times had now changed. Javanese nationalism had been given its institutional expression in the Committee for Javanese Nationalism, with the support of Budi Utomo and Prince Mangku Negara VII. ${ }^{30}$ Soetatmo and his colleagues were confident that their historical task was to give order to the present chaos of the pergerakan and thus to guide the time of madness to the time of light. Thus, the basic question they addressed was how to perform this task. They answered this question by formulating an ideology they felt would be capable of "reconstructing" the once great Javanese culture and guiding the pergerakan. Their search for the ideal Javanese culture to be reconstructed led them to the era of Majapahit.

What did they, then, see as the basic principles of Javanese culture? The first was concerned with the concept of wisdom (wijsheid). Each issue of their journal Wederopbouw carried the following formula on its front page: "Beauty, which controls Power. Power, which possesses Beauty. Wisdom, which bestows legitimacy." ("Schoonheid, die Macht beheerscht. Macht, die Schoonheid bezit. Wijsheid, die rechtvaardigd.") Here Soetatmo's concepts of the combination of beauty and power are reminiscent of the concept of Power (kasekten) which Anderson has analyzed. The concept of kasekten was the core concept of the traditional Javanese ruling ideology, in which the realization of paradise, tata tentrem karta raharja (order-tranquillity-prosperity-welfare), was conceived as possible only when the kasekten was concentrated in the person of the king. ${ }^{31}$ But Soetatmo was not concerned with the "Power" aspect of the pergerakan. What was crucial to his idea was his concept of wisdom, which enabled him to reformulate the

26. Ibid., p. 23 .

27. Ibid., p. 24 .

28. Ibid., p. 5 .

29. Ibid., p. 20.

30. "Prae-advies van A. Muhlenfeld," pp. 26-27.

31. See Anderson, "Idea of Power." 
principles of democracy and sama rata sama rasa. Employing the family as a metaphor for the state, he argued in Sabdo-Panditto-Ratoe as follows:

Equality and brotherhood ... . are also preached by the wise; but not the quality of democracy, which speaks of equal rights, but the equality in the family, where the eldest son plays a more important part in carrying domestic burdens and duties, and so enjoys more rights than his younger, still playing-around, brother. There are no equal rights in such a family and yet among the children there rules equality and brotherhood in the fullest sense of the word. ${ }^{32}$

In other words, "what Father says is good, because Father is wise! That is the ideal of a family, and thus also of a state." ${ }^{33}$ What was needed, in Soetatmo's view, were wise men who would guarantee a democracy based on the principle of wisdom.

With Soetatmo's formulation of the concept of wisdom, the traditional ruling ideology constructed around the concept of kasekten underwent an interesting transformation. Democracy and sama rata sama rasa were the spirit of the time which no one could resist frontally. What Soetatmo did was to reformulate the concept as "democracy and wisdom" under which "sama rata sama rasa" could be guaranteed. Thus, although he put forward the reconstruction of Javanese culture as the task, he first reinterpreted the traditional Javanese ruling ideology in the context of the age of pergerakan and then reified it as Javanese culture.

The second principle of Javanese culture enunciated by Soetatmo, the concept of opvoeding, was directly related to the first. As we have seen, for Soetatmo opvoeding meant the wisdom concentrated in the person of a pandita bringing about the moral perfection of his disciples. What was important in his concept of opvoeding was, then, the physical and spiritual proximity of the pandita and the disciples. The relationship developing between them in the process of moral upbringing was, in his view, the ideal type of relationship, with all the qualities of democracy and wisdom. This should be the basis of reconstructing the kawula-gusti relationship in the age of pergerakan. In the world of wayang, the eldest of the Pendawa princes, Prabu Yudisthira, was the pandita-ratu, who was the ideal king because he acquired the truth of the transcendental law of the cosmos and the divine through his meditation and his possession of the holy book Kalimasada. In Soetatmo's view, what was lacking in the pergerakan was a pandita-ratu like Prabu Yudisthira, who could restore kawula-gusti relations with the people. In Soetatmo's eyes, the age of pergerakan was a time of chaos only because the pandita-ratu had disappeared. Power was already there in the pergerakan. The only task left was for the wise, who were the pandita, to guide the pergerakan. Democracy could be realized only with the wisdom of a pandita-ratu. Soetatmo thus formulated the proposition: "Democracy without wisdom is a catastrophe for all of us." 34 For Soetatmo, the people were, in the end, the object of politics. The people should be led by the leaders. In other words, the people could become the engine for realizing the golden age only when they united under the pandita-ratu.

Javanese nationalism was therefore in essence an ideology of restoration, proposing the reconstruction of Javanese culture and kawula-gusti relations in the age of pergerakan. No wonder Prince Mangku Negara VII, who had "a modern enlightened king" as his ideal, gave strong moral and financial support to the

32. Soetatmo, Sabdo-Panditto-Ratoe, p. 26.

33. Ibid., p. 23.

34. Ibid., p. 24. 
Committee for Javanese Nationalism. The concepts of wisdom and opvoeding were the key to reconstruction and the Javanese nationalist leaders assumed that task. It was thus quite natural that the political community they imagined only covered Java and Madura, because in the end only in that domain was Javanese culture historically and culturally meaningful.

\section{Reincarnation of the Satria}

While Soetatmo went back historically to the era of Majapahit in his search for the pure and ideal type of Javanese culture to be reconstructed in the age of pergerakan, Tjipto saw Majapahit as the golden age of the past but not likely to be reconstructed in the future. He did not seek the model of the time of light in the era of Majapahit. It is worth noting his remark at the Congress that "the time has changed and so have we together with it." Here, Tjipto was explicitly denying the relevance of the traditional Javanese ruling ideology reinterpreted and reified by Soetatmo as "Javanese culture." In his view, Javanese culture had only been relevant in the past, when the population was small and when the people could enjoy all the products of the soil. At that time, realization of the ideal society of "tata tentrem karta raharja" and not increase of the people's welfare was the task of the king. But now times had changed. Dutch colonial rule was draining the wealth of the Javanese soil from the people, and the enormous population growth had resulted in their increasing pauperization. Therefore, in Tjipto's view, reconstruction of Javanese culture was the wrong prescription for the age of pergerakan. The urgent task for all Javanese was to improve the people's welfare, and for this purpose it was absolutely necessary to promote intellectual training and to acquire the more advanced Western technology and science. ${ }^{35}$

Tjipto's view of the changes contrasted with that of Soetatmo. Soetatmo saw the people as the object to be led, as the potential kawula of the self-styled pandita-ratu; but Tjipto believed that, together with the changing times, the people had also changed, to become not the object but the subject of the times. ${ }^{36}$ The people were not simply waiting for leadership to come from the pandita; in itself the pergerakan signified the coming of the time of light. Here Tjipto's understanding of the time of pergerakan was diametrically opposed to that of Soetatmo. To discuss this point more fully, let us now look at Tjipto's attitude toward how he thought he should live his life in the time of pergerakan.

Tjipto saw the time in which he lived as the time of madness, not because the world was full of chaos as Soetatmo believed, but because Dutch colonial domination and the priyayi order which buttressed it were suffocating the creativity and the initiative of the Javanese. This sense of living in the time of madness, then, did not guide him back to the era of Majapahit, but led him to search for a model for the conduct of his life. To put it in another way, Tjipto was primarily concerned with the moral question, which guided him to his own understanding of the pergerakan and his position in it.

Tjipto's concern with the moral question is very apparent in his writings even before his exile to Holland in 1913. For instance, he presented a paper entitled "Some observations on the Javanese, their history and their ethics" at the First

35. Tjipto Mangoenkoesoemo, "Iets over Javaansche Cultuurontwikkeling," p. 19.

36. This point was explicitly made by Tjipto again in his Het Communisme in Indonesië: Naar Aanleiding van de Relletjes (Bandung: n.p., 1927), as follows: "Het Volk zijn niet alleen Object, maar ook Subject." 
Indiers Congress, held in Semarang in March 1913. ${ }^{37}$ In this paper, he strongly criticized Dutch colonial rule for its authoritarian character (het prentah-wezen) and its capitalist exploitation, and he accused the priyayi of losing their integrity and autonomy and becoming the mandur (foreman) of the Dutch. In his view, half a century before the priyayi had still retained at least some integrity and autonomy, but since then they had gradually lost their autonomy and had become a mandur meddling in the domestic problems of the Javanese for their Dutch masters. In the end the Javanese had lost their independent and firm character, which had in turn created decay on Java. Looking at Java's history under Dutch colonial domination in this perspective, Tjipto asked in the paper, "whose will should we inherit with great pride in such a time of decay?" ${ }^{38}$ Tjipto argued it was the will of Dipanegara as a fighter against moral decay.

What have we to see in Prince Dipanegara? An ordinary rebel, who, driven by his pursuit of profit or ambition, brought about the scourge of war to the land and the people? Was it stupid fanaticism that led him to the path of revolt? I think I can rightly answer these questions negatively. There was a great task for him to fulfill. He felt that he was predestined to carry out this task. Now, with great tenacity and energy he assumed the task of his life. He failed, but I think you as well as I should not judge anyone's work exclusively in terms of its success. It is not my intention here to subject the strength of Dipanegara to judgment. My intention is rather to show that in contradiction with what some people perceive, the Javanese have a very sound moral basis, on which they should be able to build a moral fund, and that, we may cheerfully agree, we have the possibility of reviving our golden years. ${ }^{39}$

Here it is extremely important to note that Tjipto, in the time of madness, was determined to inherit and live up to the moral will of Dipanegara. Inheriting Dipanegara's will, he was determined to live a satria's life, for, in Tjipto's eyes, Dipanegara was the epitome of a satria fighting against moral decay. It is also important to note that, with Tjipto's idea of inheriting the moral will of Dipanegara, the concept of satria underwent a subtle transformation. Tjipto's concept of satria was divorced from its original ascriptive connotation, such as bangsawan (aristocrat) or priyayi, and signified only the moral quality of the person.

His understanding of the pergerakan was closely related to his own decision to live a satria's life as he redefined it. In Tjipto's view, the pergerakan signaled the awakening and moral revival of the people, producing satria, morally upright and politically independent subjects of the time. Thus it offered the possibility of the golden age being realized through the transformation of the Javanese into satria, whom Tjipto called the "Indiers."

Why then did Tjipto see the pergerakan producing satria as politically independent subjects? To answer this question, we now have to turn to his discussion on the satria in the wayang. By comparing Tjipto's argument regarding the wayang with that of Soetatmo, we will consider how his concept of democracy, his idea of Indies nationalism, and his own personal decision to live a satria's life were logically related.

37. Tjipto Mangoenkoesoemo, lets over den Javaan, ziin Geschiedenis en zijn Ethiek, rede uitgesproken op het Eerste Indiers Congres gehouden te Semarang (21-23 Maart 1913) (Semarang: n.p., 1913).

38. Ibid., p. 17 .

39. Ibid., p. 21 . 
Tjipto and Soetatmo presented contrasting views on what should make a genuine satria. According to Soetatmo, the wayang was "the world of imagination in which the fragments of the Truth play their assigned roles with admirable devotion in accordance with the plan of the guru, the dalang." The "truth" that the whole of wayang manifested could be understood only by looking at the dominant theme of the wayang, namely the fight of the satria with the buta (giant). Soetatmo saw in "the beautiful and calm person of Arjuna" the perfect image of the satria, "unmoved and still-standing with firm will and enormous courage," and in Cakil the picture of "the violent greedy man with sly and inconstant mind, drunken on the delusion of power and trusting only in the force of his arms and the sharpness of his teeth." The central theme of wayang was, then, the fight between the two and the ultimate victory of the satria over the buta.

What was the meaning of this theme? Soetatmo argued that the key to understanding it lay in the fact that the three clowns (punakawan), Semar, Gareng, and Petruk were the attendants of Arjuna and his descendants and not of Yudisthira or Bima. With the help of these punakawan, only Arjuna and his descendants could save the Pendawa. In Soetatmo's interpretation, Semar signified samar, which meant something unknown, inexpressible, and only to be sensed. In short, Semar signified the divine, the very essence of all forms of existence. Likewise, Nala Gareng signified nala garing, the thirsty heart, meaning a firm will and strict asceticism, and Petruk-kanthong-bolong, unlimited tolerance. Therefore, in Soetatmo's view, Semar signified the "truth," while Gareng and Petruk signified the means to reach it. The genuine satria should possess these qualities, as exemplified by the fact that Arjuna was always attended by the punakawan. The satria should sense (meRasa) something unknown and inexpressible by devoting himself to the ascetic life and meditation, without any weapons but tolerance, and, once having sensed the truth, he should engage himself in the fight for the right. ${ }^{40}$

But Soetatmo was faced with the fact that in the pergerakan the leaders were seen as satria. Even Soewardi Surjaningrat, who, with Soetatmo, established Taman Siswa, depicted Mas Marco, then a leading member of the Solo SI, as a satria when Marco was arrested in 1915. In an open letter to Marco, Soewardi wrote as follows:

Indeed it is not easy and pleasant to defend the nation [bangsa], but it is our duty. We should not give up our hope. However big our sacrifice, we are all obliged to sacrifice ourselves if we need to. That is our happy duty. Don't be discouraged. There are still tens of satria candidates who have the courage to fight against buta. . . . Remember, it is not those with rank or title who are happy. For me, the happiest thing is in my mind. With this persdelict you [saudara] have sacrificed yourself and all the punishment is like a medal of honor [bintang kehormatan] for you, that is the symbol of your happiness. Now in my eyes your rank is high indeed, because it is already apparent that your happiness lies in the defense of the nation. Don't think that there will be no one to succeed you in your work. I feel tens of people will succeed you. With this persdelict, many people will enter the field of our movement [medan pergerakan kita]. Courageous because true [Berani karena benar]. ${ }^{41}$

And with this transformation of the concept of satria, the meaning of bui (prison) also changed. Bui was now increasingly seen as the place for tapa (asceticism) and semadi (meditation), from which satria, pergerakan leaders, would emerge with

40. Soetatmo Soeriokoesoemo, "Het Heilige Schrift in Beeld: De Wajang," Wederopbouw, 6, 1-3 (1923), pp. 30-39.

41. Sarotomo [Solo], 1915, pp. 125-26. 
their moral power strengthened. But in Soetatmo's eyes, the claim that such pergerakan leaders were satria was a culturally unfounded, pretentious allegation unless these leaders were guided by the wise. Thus, in the following words Soetatmo criticized pergerakan leaders who styled themselves satria:

We should have regard only for the bambang [son of a holy man] who comes from the mountains (pertapan) after years of stay with his grandfather ... Abiyoso and who was always accompanied by the trio, Semar, Gareng and Petroek. For it is not the bambang who resides permanently in the town and is not innocent of living the life of luxury who is chosen by the trio as their master. ${ }^{42}$

The world of pergerakan was the world of satria; yet the satria of the world of pergerakan were not necessarily the genuine satria, but sometimes satria maling, those driven by their own greed. Soetatmo felt it urgent to assume the role of pandita who could bring up genuine satria.

How was Tjipto's interpretation of what should make the genuine satria different from Soetatmo's and how was his interpretation of wayang related to his understanding of the pergerakan? The most important and crucial difference between Tjipto's and Soetatmo's interpretation lies in the fact that, while Soetatmo saw the attendance of the punakawan as crucial for genuine satria, Tjipto emphasized the importance of the trials they faced in tempering the character of the satria. Tjipto talked about Abimanyu and his grandfather in great detail, but the episodes he cited to illustrate that Abimanyu was a genuine satria were always those which emphasized his firm will and independent mind. ${ }^{43}$

In the story of Abimanyu, there is an episode in which he, learning that his father is Arjuna, asks his grandfather, the pandita Abiasa, to give him permission to go to Arjuna. The grandfather's answer is negative, but Abimanyu continues to press his request. Tjipto describes and analyzes Abimanyu's conversation with his grandfather as follows:

Then he goes on asking for permission.

- No, grandfather! You can't reject my request. Because I have now made up my mind to visit my father. If you tie me up, I'll tear myself loose. If you lock me up, I'll break away.

With satisfaction the grandfather looks at his youthful son. He takes pleasure in the fact that his upbringing has borne fruit.

- Good, my son! I know that I haven't taught you the qualities of a satria for nothing. I notice your satria-ness ( $k$ satrya-aard) in your determination, which cannot be weakened by any kind of difficulty. No, every time you face difficulty you will find a strong spur to make more effort and your determination will become firmer. Once again you will do honor to your caste by your determination. Go, go with my blessing. But go in the company of Semar and his sons, who can show you the way.

An analysis of this episode and the lesson contained in it.

The dalang teaches us here that firmness of character beseems a man, at least he who will deserve the lofty title of "man" in the fullest sense of the word. Nothing can dissuade him from the plan he has once conceived. No difficulty can be too great to be overcome. No, each difficulty must be

42. Soetatmo Soeriokoesoemo, "Het Heilige Schrift," p. 38.

43. Tjipto Mangoenkoesoemo, De Wayang als Kultuuruiting van ons volk: Inleiding voor het $X I$ Indiers Congres (Semarang: n.p., 1921), especially pp. 25-31. 
a spur for us to make more effort. The divine has placed difficulties in our way so that we become conscious of our hidden strength and exert it. ${ }^{44}$

Here, Tjipto was referring to satria not only in the world of wayang but also in the world of the pergerakan. He emphasized the satria's determined will and firm character, and his persistence in the face of difficulties. In Tjipto's view, the difficulties were not obstacles but trials ordained by the gods, for only through these trials could men attain a satria's qualities. The world of pergerakan was indeed full of trials, and it therefore becomes clear why, in it, Tjipto saw the dawn of the golden era. There was a future in the pergerakan, because those fighting against Dutch colonial domination and the "feudal" priyayi order were in effect undergoing trials from which they would emerge as the reincarnation of satria. He called those who went through these trials the "Indiers."

\section{Conclusion}

Living in the age of pergerakan, Tjipto Mangoenkoesoemo, a proponent of Indies nationalism, and Soetatmo Soeriokoesoemo, a leader of Javanese nationalism, formulated diametrically opposing views of pergerakan and its age. Soetatmo saw chaos in the pergerakan and proposed reconstructing Javanese culture as the only way out of the time of madness. By Javanese culture Soetatmo in effect meant reinterpreting and then reifying the traditional ruling ideology of Java, in which he believed he had discovered the key to guide the pergerakan to the time of glory. Thus, in his view, the idealized kawula-gusti relations should be reconstructed. Assuming the task of pandita, he argued that order could only be introduced into the chaos of pergerakan when the people became the kawula of the pandita-ratu. Tjipto, in contrast, saw the end of the time of madness and the dawn of the time of light in the very rise of pergerakan. In his view, the evolution and liberation of Java was possible only when the people reincarnated the essence of the genuine satria, his moral quality, through uncompromising struggle against the suffocating oppression and exploitation of the Dutch-priyayi regime. The pergerakan * signified the trials through which the people would eventually emerge as the satria, the Indiers. Tjipto believed he only needed to show the Javanese people how to live a satria's life in the time of madness for their moral willpower to be revived. Tjipto inherited and tried to live up to the will of Pangeran Dipanegara, the satria who had fought against the moral death of the Javanese.

The time when Tjipto and Soetatmo engaged in their debates was the turning point of the pergerakan. It was getting more and more radical and "the iron claw" of the Dutch colonial rule was increasingly being felt. Tjipto was to be forbidden from living in Central or East Java after he led the Sarekat Hindia-Nationaal Indische Partij activities in Solo in 1919 and 1920, but even then he always remained sympathetic with the radicalism expressed in the pergerakan. Finally, in 1927, he was banished to Banda. Soetatmo, true to his task as a pandita, was to join Soewardi Surjaningrat in establishing Taman Siswa and to serve as its first President until his death in 1924 .

44. Ibid., pp. 27-28. 